\title{
Efforts of the National Center for Optics and Photonics Education (OP- TEC) to prepare the technician workforce for photonics industries
}

Dan Hull, John Souders

Dan Hull, John Souders, "Efforts of the National Center for Optics and Photonics Education (OP-TEC) to prepare the technician workforce for photonics industries," Proc. SPIE 9666, 11th Education and Training in Optics and Photonics Conference, 96660I (5 June 2009); doi: 10.1117/12.2207949

SPIE Event: Eleventh International Topical Meeting on Education and Training in Optics and Photonics, 2009, St. Asaph, United Kingdom 


\title{
Efforts of the National Center for Optics and Photonics Education (OP-TEC) to prepare the technician workforce for photonics industries
}

\author{
Dan Hull \\ Executive Director, OP-TEC \\ John Souders \\ Associate Director, OP-TEC
}

\begin{abstract}
The mission of the National Center for Optics and Photonics Education (OP-TEC) is to create a secondary-topostsecondary "pipeline" of highly qualified and strongly motivated students and to empower high schools and community colleges to meet the urgent need for technicians in optics and photonics. This paper describes the methodologies and processes OP-TEC has developed to carry out that mission. A recently completed assessment of the need for optics and photonics technicians in American industry concluded that U.S. colleges lack the capacity to produce an adequate supply. OP-TEC's challenge is to close the gap between the supply of and demand for photonics technicians. To help increase college capacity, OP-TEC has developed and implemented a recruitment process for initiating photonics programs in U.S. colleges. This paper describes the recruitment process and its results, along with the relevant support services provided by OP-TEC. In support of its mission, OP-TEC has developed curriculum and instructional materials that prepare students for the photonics workforce. To help ensure that completers of U.S. photonics programs are workforce ready, OP-TEC uses a skill-standards-based process for developing curriculum and instructional materials. This paper reviews the foundational skill standards and explains the process for integrating them into the materials development process. The curriculum and instructional materials that result from this process are also described. ${ }^{1}$
\end{abstract}

\section{KEYWORDS}

Lasers, optics, OP-TEC, fiber optics, technical programs, photonics, National Science Foundation/ATE

\section{MISSION/ORGANIZATION}

The National Center for Optics and Photonics Education (OP-TEC) is a National Science Foundation (NSF) Advanced Technological Education (ATE) National Center of Excellence. OP-TEC's mission is to create a secondary-to-postsecondary "pipeline" of highly qualified and strongly motivated students and to empower high schools and community colleges to meet the urgent need for technicians in optics and photonics. Under its current grant from NSF, OP-TEC has been awarded five million dollars over a period of four years. OP-TEC has focused its energy primarily on building the capacity of community and technical colleges to use their existing program infrastructures to train and educate photonics technicians that will meet industry's current and future need for these specialized workers.

OP-TEC is a consortium of colleges whose efforts are coordinated and directed by its PI, Dan Hull, and four Co-PI's: Dr. Fred Seeber, Dr. Chrys Panayiotou, Dr. Larry Grulich, and Dr. M.J. Soileau. The consortium of partner colleges comprises Camden County College, Indian River State College, Indiana University of Pennsylvania, Indian Hills Community College, Tri-County Technical College, Irvine Valley College, Central Carolina Community College, and Texas State Technical College. 


\section{SUPPLY AND DEMAND}

A key step in the fulfillment of OP-TEC's mission is to determine (1) the demand, now and in the future, for photonics technicians and (2) the capacity of community and technical colleges to meet that demand. In 2008, OP-TEC commissioned two studies to determine the relevant supply and demand parameters.

\subsection{Supply}

The purpose of the first study was to determine the capacity of U.S. colleges to produce photonics technicians. ${ }^{2}$ To collect this information, the study used both Internet searches and telephone surveys. The Internet searches identified postsecondary institutions in the U.S. that offer photonics instruction (from single courses to full programs) that can contribute to the training and education of photonics technicians. The telephone surveys confirmed that the identified colleges still offer this instruction and determined the number of students enrolled and the number of program completers. All the institutions that contributed to the final results of the survey indicated that they have active photonics instructional offerings (at least one course in photonics, optics, and/or laser technology) and that their former students are employed in the optics/photonics industry as a result of their participation in that instruction. The results of the survey indicated that 600-700 students are enrolled in programs that are capable of leading to technician-level employment in the photonics industry. However, only 250-300 are completing their programs each year and are available to fill industry positions.

\subsection{Demand}

To determine the demand side, OP-TEC commissioned the University of North Texas Survey Research Center to contact by telephone a large random sample of industrial companies throughout the U.S. that perform R\&D with optics, lasers, and photonics technology or are original equipment manufacturers (OEM) for R\&D companies. The goal was to determine how many photonics technicians the companies employ, the additional number they will need in 2009 , and the number they will need five years from now. Using the Laurins Publishing Company Photonics Directory (2008) and OP-TEC databases, the researchers identified a total of 3989 U.S. photonics companies. The researchers contacted over 2500 of those companies before generating a representative sample of 663 companies, of which 300 employ photonics technicians. Besides employment data, the survey collected information on the educational levels of the photonics technicians currently employed; the employers' preferences with respect to the levels of education those technicians should have; and the types of jobs photonics employers are seeking to fill. After performing a statistical analysis of the survey, the researchers issued a final report. ${ }^{3}$ The results showed that over 19,000 photonics technicians are employed in the U.S., that over 2100 additional photonics technicians will be needed next year, and that approximately 5900 will be needed in five years (2014).

When the supply and demand results are compared, it is clear that for the U.S. to meet its demand for these workers, community and technical colleges must substantially increase the numbers of their graduates and program completers. For example, let's assume that in 2010 U.S colleges can add 300 new technicians to the pool of photonics workers. This will fall far short of the 2100 workers needed. Helping to close the gap between supply and demand is one of OP-TEC's primary challenges. To meet this challenge it must empower colleges to increase enrollments in their existing photonics and photonics-related programs and to implement new programs.

In addition to the challenge of increasing college capacity, OP-TEC must work to ensure that new technicians possess the skills and knowledge necessary for success in the photonics industry. To meet this second challenge, OP-TEC must provide relevant and effective curriculum and instructional materials. The remainder of this paper addresses these two challenges and outlines OP-TEC's response to them. 


\section{INCREASING THE SUPPLY}

Increasing the supply of photonics technicians is directly related to expansion of the base of colleges that offer photonics education and training. Though simple in concept, expanding this base requires a systematic process for enabling colleges to implement photonics programs. OP-TEC has developed and is implementing an aggressive process for recruiting new colleges and assisting them in adding photonics content to their existing curricula. This process (outlined below) consists of five phases, as illustrated in Figure 1.

Phase 1: Awareness. The main purpose of this phase is to make two-year colleges (TYC), both community and technical colleges, and secondary school systems (SSS) aware of the existence of OP-TEC and its mission. In this phase, OP-TEC works to establish itself as the point-of-contact for all matters related to the education and training of photonics technicians. OP-TEC works to help the TYCs and SSSs recognize that photonics is a high-demand, high-pay technical field that is still emerging and has great growth potential.

\begin{tabular}{|c|c|c|}
\hline Phases & Actions & $\begin{array}{l}\text { Allocation of } \\
\text { Center Effort }\end{array}$ \\
\hline $\begin{array}{l}\text { 1. Awareness } \\
\text { - Understand needs } \\
\text { - OP-TEC known } \\
\text { - OP-TEC's services } \\
\text { available }\end{array}$ & $\begin{array}{l}\text { - Develop website } \\
\text { - Establish relationships between OP-TEC } \\
\text { and professional societies } \\
\text { - Publish articles and make presentations } \\
\text { - Encourage faculty and staff to attend } \\
\text { photonics education workshop }\end{array}$ & $\begin{array}{l}\text { Center staff: } 85 \% \\
\text { Partner colleges: } 15 \%\end{array}$ \\
\hline $\begin{array}{l}\text { 2. Institutional commitment } \\
\text { - Staff agrees to explore } \\
\text { need for photonics } \\
\text { education }\end{array}$ & $\begin{array}{l}\text { - Faculty and staff attend photonics } \\
\text { education workshop } \\
\text { - Follow-up with workshop attendees } \\
\text { - Establish secondary/postsecondary } \\
\text { partnerships } \\
\text { - OP-TEC assistance requested }\end{array}$ & $\begin{array}{l}\text { Center staff: } 75 \% \\
\text { Partner colleges: } 25 \%\end{array}$ \\
\hline $\begin{array}{l}\text { 3. Assessment } \\
\text { - College/partnership } \\
\text { determines best } \\
\text { photonics option }\end{array}$ & $\begin{array}{l}\text { - Select photonics-enhanced technology, } \\
\text { based on local needs } \\
\text { - Form or expand employer advisory } \\
\text { committee } \\
\text { - Obtain employer support and advice } \\
\text { - Design and develop curriculum } \\
\text { - Design labs and identify equipment }\end{array}$ & $\begin{array}{l}\text { Center staff: } 30 \% \\
\text { Partner colleges: } 70 \%\end{array}$ \\
\hline $\begin{array}{l}\text { 4. Preparation } \\
\text { - Build program } \\
\text { infrastructure } \\
\text { - Prepare staff }\end{array}$ & $\begin{array}{l}\text { - Obtain program approval and changes } \\
\text { - Develop labs } \\
\text { - Obtain equipment } \\
\text { - Recruit students }\end{array}$ & $\begin{array}{l}\text { Center staff: } 15 \% \\
\text { Partner colleges: } 85 \%\end{array}$ \\
\hline $\begin{array}{l}\text { 5. Implementation } \\
\text { - Conduct program }\end{array}$ & $\begin{array}{l}\text { - Obtain student materials } \\
\text { - Teach courses } \\
\text { - Collect data } \\
\text { - Evaluate and revise program }\end{array}$ & $\begin{array}{l}\text { Center staff: } 60 \% \\
\text { Partner colleges: } 40 \%\end{array}$ \\
\hline
\end{tabular}

Fig. 1 OP-TEC college recruitment process

Phase 2: Institutional commitment. This phase has two main objectives. One is getting TYCs and SSSs to commit to an assessment of their need for photonics programs or, if the need has already been established, commit to program implementation. The other objective is to assist institutions in developing secondary/postsecondary partnerships on which to build $4+2$ career pathways. 
Phase 3: Assessment. The main purpose of this phase is to determine the best way to implement a photonics program in a given TYC. In this phase OP-TEC works closely with the educational organization to provide survey instruments for assessing need within its service area, to provide a list (through professional societies) of potential photonics employers in its service area, and to help the organization establish an advisory board or add members to an existing board that can provide guidance in the photonics area. The primary outcomes of this phase are to:

1. Determine the educational organization's need for a photonics program and the type of photonics program required to meet that need.

2. Establish an advisory capacity for ensuring the proper implementation of the program and its continuous updating to meet future needs.

3. Design and develop curriculum and laboratories.

4. Identify required laboratory equipment.

To help meet these outcomes, OP-TEC provides program planning guides (PPG) that detail the requirements for adding photonics programs. The guides are designed to enable college decision makers to quickly grasp the implications of adding photonics to their program offerings. Figure 2 provides more detail about the PPGs.

\begin{tabular}{|c|}
\hline Content \\
\hline $\begin{array}{l}\text { Photonics as a converging/enabling technology } \\
\text { Applicable skill standards } \\
\text { Curriculum, courses, materials } \\
\text { Labs and equipment } \\
\text { Faculty requirements and training } \\
\text { Building the high school pipeline }\end{array}$ \\
\hline $\begin{array}{c}\text { Programs supported by PPGs } \\
\text { completed as of May } 2009\end{array}$ \\
\hline $\begin{array}{l}\text { Biomedicine } \\
\text { Defense and Homeland Security } \\
\text { Manufacturing } \\
\text { Optoelectronics (semiconductors, MEMS, and nanotechnology) } \\
\text { Telecommunication }\end{array}$ \\
\hline
\end{tabular}

Fig. 2 Program planning guide content and supported programs

Phase 4: Preparation. The main purpose of this phase is to help the educational organization build the infrastructure necessary to implement the program, as outlined in phase 3 (assessment). OP-TEC provides a professional development course designed to prepare faculty to present photonics topics. OP-TEC also works with faculty to locate and procure the laboratory equipment identified in phase 3 (assessment). During this phase, OP-TEC helps the educational organization prepare to implement a photonics program by assisting the organization in gaining state and/or local program approval, developing labs, purchasing equipment, training instructors, and recruiting students.

Phase 5: Implementation. In this phase, OP-TEC and its partner colleges act as advisors to ensure the successful launch of new photonics programs. OP-TEC helps educational organizations assess the effectiveness of their programs by helping them develop means for surveying their employer bases and making program adjustments as dictated by the results of the surveys. 
The process described in the preceding paragraphs is designed to achieve OP-TEC's goal of building capacity at U.S. colleges to educate and train photonics workers. The process is also designed to amplify the assets available at OP-TEC and provide a sustainable means of expanding photonics education. The success of the process will depend heavily on close collaboration between OP-TEC and educational institutions that implement new photonics programs.

Over 200 colleges are involved in the OP-TEC recruitment process. Seventy-one are beyond phase 1 (awareness) and four have reached phase 5 (implementation). As it works with the colleges, OP-TEC leverages its resources by assigning mentors from its partner colleges. The extent of this mentorship is indicated in the right column of Figure 1 as the percentage of the overall effort contributed by the partner colleges in each of the five phases. For instance, in phase 1 (awareness) little mentorship is needed, but in phases 3 (assessment) and 4 (preparation) the extent of the mentorship needed is substantial.

\subsection{Empowerment services provided by OP-TEC}

In carrying out the process outlined in the previous section, OP-TEC offers several services designed to empower colleges to advance through the process. These services can be categorized in the following five broad areas:

1. Information about photonics technology and technician careers

- Provide an overview of optics and photonics technology

- Identify technical areas in which photonics is an enabling technology

- Maintain up-to-date needs projections for photonics technicians

- Post job opportunities for photonics technicians

- Maintain a website for information exchange by members of the photonics community

2. Technical assistance in program feasibility and planning

- Identify local employers that are involved in the photonics industry

- Determine specific areas of concentration required by local photonics employers

- Assist secondary and postsecondary institutions in infusing photonics into existing technical curricula

3. Technical assistance in curriculum design and development

- Participate in organizational meetings of photonics advisory committees

- Adapt the National Photonics Skill Standards for Technicians to local and/or regional needs

- Design and develop career pathways in photonics to meet local industry requirements

- Assist educational institutions in selecting the most effective teaching models

4. Technical assistance in designing laboratories

- Provide guidance in configuring laboratories

- Recommend equipment and suppliers

- Provide cost estimates

- Assist in selecting laboratory experiments

5. Training

- Provide online training in the teaching of postsecondary optics and photonics principles

- Provide online training to enhance the understanding and implementation of photonics curricula

- Provide professional development opportunities for high school teachers to enhance their skills in presenting photonics topics 
Through these services, OP-TEC empowers colleges to design photonics programs that best meet the needs of the industries in their service areas.

\section{CURRICULUM AND INSTRUCTIONAL MATERIALS DEVELOPMENT}

During the college recruitment process, a strategic decision must be made as to what audience(s) the college will serve and what programs should be put in place to serve them. These decisions, which are typically made by advisory committees composed of representatives of industries in the colleges' service areas, usually focus on three options. (1) If a college's service area is heavily represented by photonics R\&D or laser OEMs, the college should consider implementing an AAS program in photonics. (2) If the college's service area is heavily represented by companies that use photonics as an enabling technology, the college should consider infusing photonics into the technical programs from which these employers hire their technicians. (3) A third option is the advanced certificate program, a non-degree-granting program designed to upgrade and/or update the skills of photonics technicians already employed.

OP-TEC has developed curriculum for all three options. The AAS degree (Figure 3 ) is a benchmark $4+2$ articulated program that allows effective "pipeline building" from high schools to colleges. The photonics courses listed in the postsecondary portion are supported by OP-TEC's Laser/Electro-Optics Technology Series course materials.

\begin{tabular}{|c|c|c|c|c|c|c|c|c|}
\hline & 9th grade & 10th grade & 11th grade & 12th grade & \multicolumn{2}{|c|}{ 13th year } & \multicolumn{2}{|c|}{ 14th year } \\
\hline Math & Algebra 1 & Geometry & Algebra 2 & Precalculus & & $\begin{array}{l}\text { Calculus or } \\
\text { other adv } \\
\text { math }\end{array}$ & & \\
\hline Science & $\begin{array}{c}\text { Biology/Life } \\
\text { Sciences }\end{array}$ & Chemistry & Physics & & $\begin{array}{l}\text { College } \\
\text { Physics }\end{array}$ & & Elective & \\
\hline English & English 1 & English 2 & English 3 & English 4 & English & $\begin{array}{l}\text { Tech } \\
\text { Comm/ } \\
\text { Writing }\end{array}$ & & \\
\hline Technology & $\begin{array}{l}\text { Career Mgt } \\
\text { Success }\end{array}$ & $\begin{array}{l}\text { Computer } \\
\text { Apps }\end{array}$ & $\begin{array}{l}\text { DC/AC } \\
\text { Electricity }\end{array}$ & $\begin{array}{c}\text { Digital } \\
\text { Electronics }\end{array}$ & & Elective & & $\begin{array}{l}\text { Photonics } \\
\text { Trouble- } \\
\text { shooting }\end{array}$ \\
\hline Technology & & & & $\begin{array}{l}\text { Intro to } \\
\text { Photonics }\end{array}$ & $\begin{array}{l}\text { Intro to } \\
\text { Lasers }\end{array}$ & $\begin{array}{l}\text { Light } \\
\text { Sources and } \\
\text { Wave Optics }\end{array}$ & $\begin{array}{l}\text { Laser } \\
\text { Electronics }\end{array}$ & Laser Apps \\
\hline Technology & & & & & $\begin{array}{l}\text { Geometric } \\
\text { Optics }\end{array}$ & & $\begin{array}{c}\text { Lasers/ } \\
\text { Electro-Optic } \\
\text { (EO) } \\
\text { Components }\end{array}$ & $\begin{array}{c}\text { Lasers/ } \\
\text { EO Devices }\end{array}$ \\
\hline Technology & & & & & & & $\begin{array}{c}\text { Laser } \\
\text { Technology }\end{array}$ & $\begin{array}{c}\text { Lasers/EO } \\
\text { Measure- } \\
\text { ments }\end{array}$ \\
\hline & Social Scien & s, Humanitie & History, Gove & ment, Health & & Humanities, Sc & ocial Sciences & \\
\hline
\end{tabular}

Fig. 3 AAS benchmark photonics $4+2$ curriculum

The advanced certificate (Figure 4) provides a means for already employed technicians to learn about photonics and its application in the technicians' areas of specialization. Courses that are to be taught along with the photonics course in advanced certificate programs will vary according to local industry needs. Electronics was chosen for this example, since it tends to be one of the most rapidly changing technologies in most technical fields and thus requires constant update training. 


\begin{tabular}{|l|l|l|}
\hline Semester 1 & \multicolumn{1}{|c|}{ Technology } & \multicolumn{1}{c|}{ Technology } \\
\hline Slectronic Circuits for & $\begin{array}{l}\text { Fundamentals of Light } \\
\text { and Lasers }\end{array}$ \\
\hline Semester 2 & Laser Electronics & $\begin{array}{l}\text { Elements of Photonics } \\
\text { (plus specialty modules) }\end{array}$ \\
\hline
\end{tabular}

Fig. 4 Example courses for an advanced certificate program

The photonics courses listed in Figure 4 are supported by OP-TEC's Optics and Photonics Series. Figure 5 presents the content of the courses and shows the specialty areas that can be added to the Elements of Photonics course to customize it to local industry needs. Figure 6 provides topical information on OP-TEC's Photonics Enabled Technology (PET) materials, which are specifically designed for use as specialty modules in advanced certificate programs or infusion curricula.

\begin{tabular}{|l|l|}
\hline Course 1: Fundamentals of Light and Lasers & PET Modules \\
- Nature and Properties of Light & - 4 in Manufacturing \\
- Optical Handling and Positioning & - 3 in Biomedical \\
- Light Sources and Laser Safety & - 3 in Homeland Security \\
- Basic Geometrical Optics & - 3 in Environmental Monitoring \\
- Basic Physical Optics & - 2 in Optoelectronics \\
- Principles of Lasers & \\
Course 2: Elements of Photonics & \\
- Operational Characteristics of Lasers & \\
- Specific Laser Types & \\
- Optical Detectors and Human Vision &
\end{tabular}

Fig. 5 Content of photonics advanced certificate and infusion courses

\begin{tabular}{|c|c|}
\hline $\begin{array}{l}\text { Manufacturing } \\
\text { - Laser Welding and Surface Treatment } \\
\text { - Laser Material Removal: Drilling, Cutting, } \\
\text { and Marking } \\
\text { - Lasers in Testing and Measurement: } \\
\text { Alignment, Profiling, and Position } \\
\text { Sensing } \\
\text { - Lasers in Testing and Measurement: } \\
\text { Interferometric Methods and } \\
\text { Nondestructive Testing } \\
\text { Biomedicine } \\
\text { - Lasers in Medicine and Surgery } \\
\text { - Diagnostic Applications of Lasers } \\
\text { - Therapeutic Applications of Lasers }\end{array}$ & $\begin{array}{l}\text { Homeland Security } \\
\text { - Lasers in Forensic Science and } \\
\text { Homeland Security } \\
\text { - Infrared Systems for Homeland Security } \\
\text { - Imaging System Performance for } \\
\text { Homeland Security Applications } \\
\text { Environmental Monitoring } \\
\text { - Basics of Spectroscopy } \\
\text { - Spectroscopy and Remote Sensing } \\
\text { - Spectroscopy and Pollution Monitoring } \\
\text { Optoelectronics } \\
\text { - Photonics in Nanotechnology } \\
\text { - Photonics Principles in Photovoltaic Cell } \\
\text { Technology }\end{array}$ \\
\hline
\end{tabular}

Fig. 6 PET Modules for the advanced certificate and infusion curriculum

A typical infusion curriculum is shown in Figure 7. This curriculum treats photonics as an enabling technology in manufacturing. Once again, the two courses in OP-TEC's Optics and Photonics Series are embedded, thus 
enabling students to learn the role of photonics in materials processing. The manufacturing modules listed are the four PET manufacturing modules listed in Figure 6.

\begin{tabular}{|c|c|c|c|c|c|c|}
\hline Grade & English & Math & Science & Technology & Technology & Other \\
\hline $\begin{array}{c}13 \\
\text { Semester } 1\end{array}$ & $\begin{array}{c}\text { English } \\
\text { Composition }\end{array}$ & $\begin{array}{l}\text { College Alg } \\
\quad \& \text { Trig }\end{array}$ & $\begin{array}{l}\text { Electronic } \\
\text { Control } \\
\text { Devices }\end{array}$ & $\begin{array}{l}\text { Computer } \\
\text { Apps Mfg }\end{array}$ & $\begin{array}{l}\text { Principles of } \\
\text { Machining } 1\end{array}$ & Eng Design \\
\hline $\begin{array}{c}13 \\
\text { Semester } 2\end{array}$ & Hum Elect & $\begin{array}{l}\text { Precalculus } \\
\text { or Math } \\
\text { Models } \\
\end{array}$ & Gen Phy 1 & $\begin{array}{l}\text { Advanced } \\
\text { CAD }\end{array}$ & $\begin{array}{l}\text { Materials and } \\
\text { Mfg Processes }\end{array}$ & Hum Elect \\
\hline $\begin{array}{c}14 \\
\text { Semester } 1\end{array}$ & Tech Writing & & $\begin{array}{l}\text { Fundamentals } \\
\text { of Light and } \\
\text { Lasers }\end{array}$ & $\begin{array}{l}\text { Electromech } \\
\text { Devices }\end{array}$ & $\begin{array}{c}\text { Statistical } \\
\text { Process \& QC }\end{array}$ & Econ \\
\hline $\begin{array}{c}14 \\
\text { Semster } 2\end{array}$ & & Tech Elect & $\begin{array}{l}\text { Elements of } \\
\text { Photonics and } \\
\text { Mfg Modules }\end{array}$ & $\begin{array}{l}\text { Metrology } \\
\text { and QC }\end{array}$ & $\begin{array}{l}\text { Automated } \\
\text { Mfg Systems }\end{array}$ & Tech Elect \\
\hline
\end{tabular}

Fig. 7 Infusion curriculum for manufacturing

\subsection{Instructional materials development and updating}

Curriculum provides a pathway that enables students to achieve academic goals in predefined structures that enhance their learning. However, even if a curriculum meets students' goals and helps them to learn, it is not valuable unless it uses instructional materials that are relevant to the workplace and meet the needs of employers.

The process used to develop OP-TEC's instructional materials treats employer needs as foundational. Figure 8 depicts the development process as a pyramid.

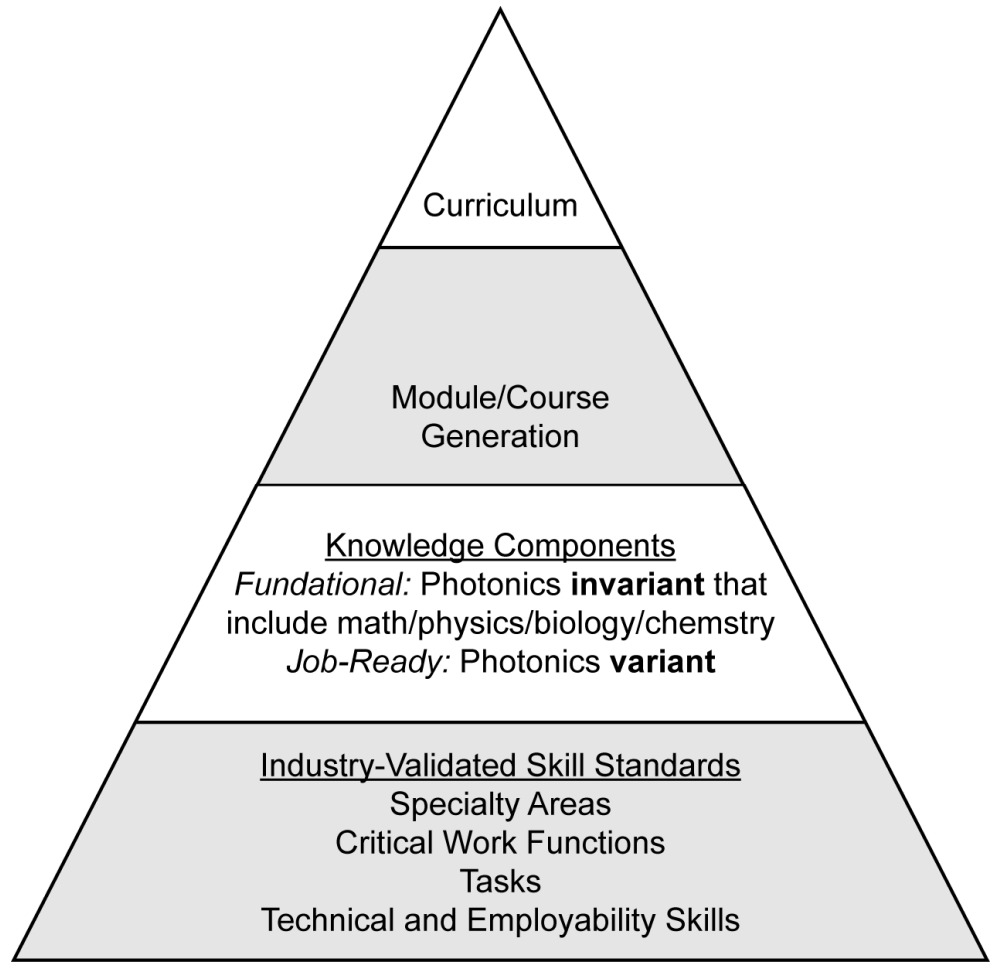

Fig. 8 OP-TEC instructional materials development process 
At the base of the pyramid are industry-validated skill standards. Skill standards are employer specifications for the knowledge and skills required for success in specified technical areas. OP-TEC developed The National Photonics Skill Standards for Technicians in 1995. Because photonics applications have undergone rapid change in the last decade, the standards have been revised twice; the third edition was completed in 2008. The revision efforts were led by photonics industry representatives and reflect their inputs as to the current needs of the U.S. photonics industry. Updates and revisions of the skill standards are critical in maintaining the currency and relevance of the instructional materials based on the standards. All OP-TEC materials referenced in this paper are based on these standards and have been or are being updated to reflect changes made in the third edition. Figure 9 provides more detail on the structure, organization, and components of the standards. Copies can be downloaded from the OP-TEC website (www.op-tec.org).

\begin{abstract}
Photonics Skill Standards
1. Specifies the knowledge and skill requirements for a variety of technicians in the photonics industry

2. Provides the foundation for AAS curriculum and materials development in photonics technology

3. Can be adapted by local employers for curriculum design at a particular college

4. Provides benchmark $(4+2)$ curriculum framework, infusion curriculum, and advanced certificate

5. Identifies six specialty areas for photonics technicians
\end{abstract}

\section{Critical Work Functions}

General areas of responsibility or functions that are required of a technician working in a specialty area

Example: Assemble various fiber-optic components and modules into subsystems and understand their function

\section{Organization of the Standards}

- Six specialty areas

- Critical work functions for each specialty

- Tasks

- Skills

- Employability and

- Technical

\section{Technical and Employability Skills}

Basic abilities that are necessary for a technician to perform a task

Examples:

- Technical: Test and verify initial source output and launch angles at source/fiber interface

- Employability: Navigate the Internet to gather task-related information

Fig. 9 Details on the structure, organization, and components of OP-TEC's National Photonics Skill Standards for Technicians

\section{SUMMARY}

This paper has presented two of the major challenges facing OP-TEC: (1) increasing the capacity of U.S. colleges to produce photonics technicians and (2) developing and maintaining relevant, up-to-date curriculum and instructional materials. Through OP-TEC's partner colleges and the generous support of the National Science Foundation, these challenges are being met. OP-TEC has developed processes for assisting colleges in implementing photonics programs and providing curriculum and instructional materials to ensure the work-readiness of program completers. These processes and instructional products are resources that can be used internationally in building the strength of the photonics technician workforce. We invite our international colleagues to review and implement these processes and give us feedback on their effectiveness. It is our hope that through this feedback we can make even greater strides in filling industry's need for highly skilled technicians. 


\section{REFERENCES}

[1] Note on organization: The figures that appear in this paper are also used in the ETOP 2009 presentation of the same title. It is the authors' intent that by coordinating the paper with the presentation, they will better enable conference attendees to understand the topic and its implications.

[2] Hull and Gutzwiller, Two-year College Enrollment and Completion Rates: An Estimation of Workforce Supply for Technicians in Optics, Photonics, and Laser Technology, OP-TEC Working Paper Series, Working Paper \#5, 2008

[3] Hull, Ruggiere, and Illich, Photonics Technician Employment in the United States: An Industry Survey of Current and Future Demand in 2009 for Education and Training Programs, OP-TEC Monograph, May 2009 